\title{
EVALUATION OF LE-CONTE PEAR SEEDLINGS ON DIFFERENT ROOTSTOCKS IN THE NORTH MIDDLE NILE DELTA REGION
}

\author{
M. A. M. Soliman and M. M. S. Abo El-Enien \\ Horticulture Res. Inst. Agric. Res. Center, Giza, Egypt
}

Received: May. 4, 2016

Accepted: Jun. 1, 2016

\begin{abstract}
The present investigation was carried out during the two successive growing seasons 2014 and 2015 at Sakha Horticultural Research Station Farm, Kafr EL-Sheikh Governorate, in North Middle Nile Delta, Egypt, to evaluate the impact of three pear rootstocks (Pyurs communis, Pyrus beutilifolia and Pyrus calleryana) on counteracting the adverse effects of heavy clay soil affected with saline alkaline in the North Middle Nile Delta region on growth, leaf water relations and mineral contents of the widespread pear cv. in Egypt namely "Le Conte". The main results can be summarized as follows:

Pear plants budded on P. beutilifolia or $P$. calleryana rootstock significantly increased most of growth parameters (plant height, stem diameter growth percentage, total shoot lengths, leaf area, and specific leaf weight) and leaf photosynthetic pigments content (chlorophyll $A$ and $B$ ). With regard to leaf total water and free water content, plants grown on $P$. beutilifolia rootstock gave the highest values followed by those budded on $P$. calleryana in this respect. On the contrary, bound water content and water deficit percentage were increased in plants budded on $P$. communis. With respect of proline content $P$. communis rootstock had significantly higher values while $P$. calleryana recorded lowest values. Pear plants budded on $P$. calleryana rootstock had the right leaf- $\mathrm{N}$ content, while the right leaves in $\mathrm{P}, \mathrm{Na}$ and $\mathrm{Cl}$ content recorded by plants budded on $P$. communis. However, $K$ percentage was increased in pear leaves which budded on $P$. beutilifolia a followed by $P$. calleyana rootstock. These results suggested that, $P$. beutilifolia may have a salt exclusion mechanism in the root, and this character is maintained even if scion cultivars were budded. Therefore, $P$. beutilifolia rootstock followed by $P$. calleryana are a useful rootstocks for pear cultivation under saline alkaline conditions than the $P$. communis rootstock.
\end{abstract}

Key wards: Le Conte" pear, vegetative growth, salinity, water relations, leaf mineral content.

\section{INTRODUCTION}

"Le Conte" is the main pear cultivar that widely grown in Egypt. It is well known that several factors affect the productivity of pear trees, i.e. rootstock and salinity. Salinity is one of the most brutal environmental factors limiting the productivity of crop plants because most of the crop plants are sensitive to salinity caused by high concentration of salts in the soil, and the area of land affected by it is increasing day by day. For all important crops, average yields are only a fraction - somewhere between $20 \%$ and $50 \%$ of record yields, these losses are mostly due to drought and high soil salinity (Shrivastava and Kumar, 2015). In Egypt, approximately 0.9 million ha. (2.1 million Fed.) Suffer from salinization problems in the cultivated irrigated areas. Furthermore, $60 \%$ of the cultivated lands in the Northern Delta, $20 \%$ of the Southern Delta and Middle Egypt, and $25 \%$ of the Upper Egypt regions are all salt-affected (Abdel-Hafez, 2011). Salinity can negatively affect plants through three limited components: osmotic, nutritions and toxic stresses (Lauchli and Epstein, 1990 and Munns, 1993). When exposed to salinity, growth and development tend to decline, with consequent reduction in their economic 
value. Pear trees are generally sensitive to salinity (Francois and Maas, 1994) and are damaged by exposure to relatively low salinity for long periods (Okubo et al., 2000). Important factor influencing pear productivity is rootstocks. Most fruit trees are commonly propagated on rootstocks, rather than begin grown on their own roots. The selection of a suitable rootstock is a significant economic factor in fruit culture (Wheaton et al., 1991). In pears, using the rootstocks showed significant growth and scion contents of nutrient elements (Robbani et al., 2006 and Ma et al., 2005) and are important factors in the salt tolerance of fruit crops, which are sensitive to salinity and susceptible to toxic effects of $\mathrm{Na}$ and $\mathrm{Cl}$ (Mass and Hoffman, 1977).

The present study carried out to evaluate growth, some physiological properties and leaf nutrient content of "Le Cote" pear seedlings budded on different rootstocks in the North Middle Nile Delta region condition, which soil are heavy clay soil affected with saline alkaline.

\section{MATERIALS AND METHODS}

This investigation was carried out during the two successive growing seasons 2014and 2015 at Sakha Horticultural Research Station Farm, Kafr EL-Sheikh Governorate, in North Middle Nile Delta, Egypt ( The site is located at $3107 \mathrm{~N}$ latitude and $3057 \mathrm{E}$ longitude with an elevation of about 6 meters above mean sea level ), to study the tolerance of Le Conte pear seedlings budded on Pyurs communis, Pyrus beutilifolia and Pyrus calleyana rootstocks to salinity and alkalinity under Kafr EL-Sheikh Governorate conditions. The seedlings planted on heavy clay soil at $5 \times 5$ metre apart and irrigated by surface irrigation. Some chemical and physical characteristics for the experimental soil site were presented in Table (1\&2). The metrological data of the studied period were presented in Table (3).

The selected trees were in a good health condition and uniform in vegetative growth. The used experimental design in this present study is randomized complete blocks with five replicates with six seedlings for each replicate. All agricultural practices were carried out according to the crop and the area.

Table (1): Some chemical characteristics for the studied soil at different depths.

\begin{tabular}{|c|c|c|c|c|c|c|c|c|c|c|c|}
\hline \multirow{2}{*}{$\begin{array}{c}\text { Soil } \\
\text { depth } \\
(\mathrm{c} \mathrm{m})\end{array}$} & \multirow{2}{*}{$\mathrm{pH}$} & \multirow{2}{*}{$\begin{array}{c}\mathrm{EC} \\
(\mathrm{ds} / \mathrm{m}\end{array}$} & SAR & \multirow{2}{*}{$\mathrm{Esp}$} & \multicolumn{4}{|c|}{$\begin{array}{c}\text { Soluble cations } \\
(\mathrm{Meq} / \mathrm{L})\end{array}$} & \multicolumn{3}{|c|}{$\begin{array}{c}\text { Soluble anions } \\
\text { (Meq/L) }\end{array}$} \\
\cline { 6 - 12 } & & & & & $\mathrm{Na}^{+}$ & $\mathrm{Ca}^{+2}$ & $\mathrm{Mg}^{+2}$ & $\mathrm{~K}^{+}$ & $\mathrm{HCO}_{3}^{-}$ & $\mathrm{Cl}^{-}$ & $\mathrm{SO}_{4}^{--}$ \\
\hline $0-30$ & 8.42 & 4.03 & 7.81 & 11.09 & 22.5 & 5.85 & 10.75 & 0.35 & 4.7 & 12.0 & 22.75 \\
\hline $30-60$ & 8.45 & 4.22 & 13.37 & 17.37 & 31.0 & 3.45 & 7.30 & 0.10 & 3.15 & 9.6 & 29.1 \\
\hline $60-90$ & 8.60 & 4.29 & 14.06 & 18.09 & 30.0 & 3.80 & 5.30 & 0.15 & 1.55 & 7.2 & 30.50 \\
\hline Mean & 8.49 & 4.18 & 11.75 & 14.18 & 27.83 & 4.37 & 7.78 & 0.20 & 3.13 & 9.6 & 27.45 \\
\hline
\end{tabular}

EC: were measured in the extract of soil paste at $25 \mathrm{C}^{0}, \quad \mathrm{pH}$ : soil water suspension $(1: 2.5)$ 
Evaluation of le-conte pear seedlings on different rootstocks

Table (2): Some physical characteristics and soil water constants for the studied soil at different depths.

\begin{tabular}{|c|c|c|c|c|c|c|c|c|c|c|}
\hline \multirow{2}{*}{$\begin{array}{c}\text { Soil } \\
\text { depth } \\
(\mathrm{cm})\end{array}$} & \multicolumn{4}{|c|}{ Particle size distribution } & \multirow[t]{2}{*}{$\begin{array}{c}\mathrm{K} \\
\mathrm{Cm} / \mathrm{d}\end{array}$} & \multirow[t]{2}{*}{$\begin{array}{c}\mathrm{IR} \\
\mathrm{Cm} / \mathrm{h}\end{array}$} & \multicolumn{3}{|c|}{$\begin{array}{c}\text { Soil moisture } \\
\text { characteristics }\end{array}$} & \multirow{2}{*}{$\begin{array}{c}\text { Bulk } \\
\text { Density } \\
(\mathrm{kg} / \mathrm{m})\end{array}$} \\
\hline & $\begin{array}{l}\text { Sand } \\
(\%)\end{array}$ & $\begin{array}{l}\text { Silt } \\
(\%)\end{array}$ & $\begin{array}{l}\text { Clay } \\
(\%)\end{array}$ & $\begin{array}{l}\text { Soil } \\
\text { texture }\end{array}$ & & & $\begin{array}{l}\text { F.C } \\
(\%)\end{array}$ & $\begin{array}{l}\text { WP } \\
(\%)\end{array}$ & $\begin{array}{l}\text { AW } \\
(\%)\end{array}$ & \\
\hline $0-30$ & 15.76 & 31.70 & 52.54 & \multirow{5}{*}{ clayey } & \multirow{5}{*}{2.15} & \multirow{5}{*}{0.65} & 42.50 & 22.6 & 19.90 & 1.29 \\
\hline $30-60$ & 14.84 & 30.86 & 54.30 & & & & 40.60 & 21.8 & 18.80 & 1.36 \\
\hline $60-90$ & 14.67 & 30.61 & 54.72 & & & & 38.91 & 20.7 & 18.21 & 1.43 \\
\hline $90-120$ & 17.23 & 33.18 & 49.59 & & & & 37.98 & 19.8 & 18.09 & 1.55 \\
\hline Mean & 15.63 & 31.59 & 52.78 & & & & 39.98 & 21.23 & 18.75 & 1.41 \\
\hline
\end{tabular}

FC: Field capacity, WP: wilting point, AW: available water, IR: infiltration rate, K: hydraulic conductivity

Table (3): Mean of some metrological data for KafrEl-Sheikh area during the two growing seasons.

\begin{tabular}{|c|c|c|c|c|c|c|c|c|c|}
\hline \multirow[t]{2}{*}{ month } & \multicolumn{3}{|c|}{$T\left(C^{\circ}\right)$} & \multicolumn{3}{|c|}{$\mathrm{RH} \%$} & \multirow{2}{*}{$\begin{array}{c}\mathrm{W}_{\mathrm{S}} \\
\mathrm{m} / \mathrm{sec}\end{array}$} & \multirow{2}{*}{$\begin{array}{l}\text { Pan Evap. } \\
\text { Mm/day }\end{array}$} & \multirow{2}{*}{$\begin{array}{l}\text { Rain } \\
\text { mm }\end{array}$} \\
\hline & Max & Min & Mean & Max & Min & mean & & & \\
\hline & \multicolumn{9}{|c|}{ Season 2014 * } \\
\hline Jan & 19.22 & 7.62 & 13.42 & 91.06 & 65.35 & 78.21 & 0.52 & 1.99 & 78.74 \\
\hline Feb. & 20.68 & 8.88 & 14.78 & 89.89 & 64.04 & 76.97 & 0.73 & 2.89 & ----- \\
\hline Mar. & 24.56 & 12.45 & 18.51 & 79.48 & 50.84 & 65.16 & 1.03 & 4.46 & ------- \\
\hline April. & 26.04 & 15.87 & 20.96 & 74.20 & 43.90 & 59.05 & 1.11 & 5.30 & 8.40 \\
\hline May & 31.43 & 21.85 & 26.64 & 75.03 & 45.78 & 60.41 & 1.20 & 6.35 & 0.00 \\
\hline June & 32.44 & 23.97 & 28.21 & 74.63 & 51.27 & 62.95 & 1.34 & 6.61 & 0.00 \\
\hline July & 32.32 & 24.31 & 28.31 & 79.57 & 54.70 & 97.14 & 1.28 & 6.11 & $\ldots \ldots$ \\
\hline Agus. & 33.79 & 24.72 & 29.29 & 83.63 & 60.52 & 72.08 & 1.04 & 5.13 & ------ \\
\hline Sep. & 32.50 & 22.93 & 27.72 & 81.00 & 56.60 & 68.80 & 1.04 & 3.82 & ------- \\
\hline Oct. & 27.79 & 19.42 & 23.61 & 76.23 & 57.36 & 66.80 & 1.26 & 2.87 & $\ldots \ldots$ \\
\hline Nov. & 25.39 & 15.14 & 20.27 & 87.00 & 64.43 & 75.72 & 0.80 & 2.28 & 0.00 \\
\hline \multirow[t]{2}{*}{ Dec. } & 19.64 & 8.51 & 14.06 & 92.07 & 67.61 & 79.84 & 0.61 & 4.15 & 81.90 \\
\hline & \multicolumn{9}{|c|}{ Season $2015^{*}$} \\
\hline Jan & 20.34 & 7.55 & 13.95 & 93.69 & 70.55 & 80.55 & 0.54 & 0.61 & 20.70 \\
\hline Feb. & 20.64 & 8.19 & 14.42 & 91.90 & 67.15 & 79.53 & 0.79 & 2.52 & 16.50 \\
\hline Mar. & 22.94 & 11.71 & 17.33 & 86.10 & 56.80 & 71.45 & 0.96 & 3.14 & 26.20 \\
\hline April. & 27.50 & 15.53 & 21.52 & 81.80 & 49.80 & 65.80 & 1.07 & 4.91 & 20.20 \\
\hline May & 30.47 & 19.57 & 25.02 & 77.20 & 48.60 & 62.90 & 1.14 & 5.87 & 0.00 \\
\hline June & 32.65 & 20.60 & 26.63 & 86.23 & 52.30 & 69.27 & 0.95 & 6.56 & 0.00 \\
\hline July & 33.15 & 23.64 & 28.40 & 83.19 & 55.11 & 69.15 & 1.13 & 7.73 & $\ldots \ldots$ \\
\hline Agus. & 34.10 & 21.80 & 27.95 & 92.40 & 53.50 & 72.95 & 1.15 & 8.14 & ------ \\
\hline Sep. & 32.49 & 20.76 & 26.63 & 87.57 & 52.20 & 69.89 & 1.03 & 6.65 & ------- \\
\hline Oct. & 29.75 & 18.75 & 24.25 & 80.92 & 53.39 & 67.16 & 0.95 & 4.51 & $\ldots \ldots$ \\
\hline Nov. & 24.30 & 13.79 & 19.05 & 87.80 & 60.50 & 74.15 & 0.78 & 2.77 & 24.60 \\
\hline Dec. & 22.27 & 9.72 & 16.00 & 88.60 & 63.50 & 76.05 & 0.53 & 1.72 & 5.70 \\
\hline
\end{tabular}

$\mathrm{T}$ : temperatures, $\mathrm{RH}$ : relative humidity, Ws: wind speed

*Source: meteorological station at Sakha $3107^{-}$Nlatitude, 3057 E longitude \& with an elevation of about 6 meters above mean sea level (MSL). 


\section{Some soil physical properties, soil water constants and chemical Properties:-}

The studied soil chemical characteristics such as soil reaction $(\mathrm{PH})$ values were determined in 1:2.5 soil water suspension. Total soluble salts were measured by electrical conductivity (EC) apparatus in the saturated soil paste extract. Soluble cations and anions $\left(\mathrm{Ca}^{++}, \mathrm{Mg}^{++}, \mathrm{Na}^{+}, \mathrm{K}^{+}, \mathrm{CO}_{3}{ }^{-}\right.$ , $\mathrm{HCO}_{3}{ }^{-}$and $\mathrm{Cl}^{-}$as meq/L ) were determined in soil paste extract (Jackson ,1973). $\mathrm{So}_{4}$ as $\mathrm{meq} / \mathrm{L}$ was calculated by the difference between cation and anions. Sodium adsorption ratio (SAR) was calculated according to this equation:

$$
\begin{aligned}
& \mathrm{SAR}=\frac{\mathrm{Na}^{+}(\mathrm{meq} / \mathrm{L})}{\sqrt{\left(\mathrm{ca}^{++}+\mathrm{Mg}^{++}\right) / 2}} \\
& \mathrm{ESP}=0.8843+1.4107(\mathrm{SAR})-0.0133(\mathrm{SAR})^{2}
\end{aligned}
$$

Where: $\mathrm{Na}^{+}, \mathrm{Ca}^{++}$and $\mathrm{Mg}^{++}$are soluble sodium, calcium and magnesium as meq/L, respectively.

The studied physical characteristics and soil water constants were determined according to the (Klute, 1986).

The following data were recorded in this study:

\section{Vegetative growth:}

Plant height $(\mathrm{cm})$, total shoot length $(\mathrm{cm})$, and 20 mature leaves were sampled in July to determine leaf area $\left(\mathrm{cm}^{2}\right)$ by using a leaf area meter Model Li 3100 area- meter, and dry weight was recorded after drying at $70^{\circ}$ $\mathrm{C}$ for $42 \mathrm{~h}$., then specific leaf weight was calculated as $\mathrm{mg} / \mathrm{cm}^{2}$ according to (Ferree and Forshey ,1988). Stem diameter growth percentage calculated as follows:

Stem diameter growth $(\%)=$

$100 \times \frac{(\text { final diameter-initial diameter })}{\text { initial diameter }}$

\section{Water relation studies of leaf:}

Leaf samples were taken before irrigation for analysis. The samples were collected usually at sunrise and taken to the laboratory in will tight plastic bags with moist cloth sheet. These prepared samples were used as described later for the following determinations according to the method described by (Gosev, 1960), and modified by (Koshnirinko et al., 1970) for fruit trees during two seasons as follow:

\section{2-1- Total water content:}

Total water content was estimated by drying a known weight of the cleaned fresh green leaves in glass vials in an oven adjusted at $85{ }^{\circ} \mathrm{C}$ until constant weight, total water content was calculated by the equation :

Total water content $(\%)=\frac{\text { Fresh weight }- \text { dry weight }}{\text { Fresh weight }} \times 100$

\section{2-2- Free water content:}

Free water content was estimated by putting a known weight of cleaned green fresh leaves in a known volume of $60 \%$ sucrose solution for 2 hours, using "Penicillin" bottles. The initial and final concentration of the sucrose solution was measured by Abbi refractometer. Free water content was calculated by the equation:

$$
\mathrm{X}=\frac{\mathrm{A} \times \mathrm{B}}{\mathrm{C} \times \mathrm{D}} \times 100
$$

Where:

$X=$ the free water content of the leaves.

$A=$ solution weight.

$\mathrm{B}=$ the difference between the initial and final concentration of the sucrose solution.

$\mathrm{C}=$ the fresh weight of the leaves

$D=$ the final concentration of sucrose solution.

\section{2-3- Bound water content:}

Bound water content was calculated by subtracting free water content from total water content in each sample.

\section{2-4- Water deficit:}

10 discs about $1 \mathrm{~cm}^{2}$ in diameter were cut from the mature leaves, weighted, flooded into distilled water for some hours 
until they attain equilibrium, reweighed and oven dried at $85^{\circ} \mathrm{C}$ for 24 hours to reach a constant weight .Water deficit were calculated as (Barrs,1968) :

Water deficit $=\frac{\text { Turgid weight }- \text { field weight }}{\text { Turgid weight }- \text { oven dry weight }} \times 100$

\section{3-Chlorophyll determination:}

For Chlorophyll determination, discs about $1 \mathrm{~cm}^{2}$ of the fresh leaf samples were dipped in $10 \mathrm{ml} \mathrm{N}, \mathrm{N}$-Dimethyl Form amide solution for 48 hours at $4^{\circ} \mathrm{C}$ in the dark .Chlorophyll concentration (as $\mathrm{mg} / \mathrm{cm}^{2}$ ) fresh leaf was measured in the extraction colorimetric ally by using UV/visible spectrophotometer-LKB-Biochrom 4050 at $664 \mathrm{~nm}$ for chlorophyll-a and $647 \mathrm{~nm}$ for chlorophyll-b according to( Moran,1982), chlorophyll was calculated (as $\mathrm{mg} / \mathrm{cm}^{2}$ ) by using the following mathematic manipulation:

Ch1-a $=12.64 \mathrm{~A}_{664} \quad-2.99 \mathrm{~A}_{647}$

$C h 1-b=5.6 A_{664}+23.26 A_{647}$

Chl. Concentration $(\mathrm{mg} / \mathrm{cm} 2)=$ ch1. a or $\mathrm{b} \times \frac{\text { Solution volume }}{\text { Discs area }}$

\section{4- Leaf proline content:}

The proline content was estimated in fresh leaves according to the method described by Batels et al., (1973) and confirmed by Draz (1986).

\section{5- Leaf mineral content:}

Leaf samples consisted of 10 leaves each was collected from the tested pear trees on August of both seasons. Leaf samples were taken from the middle of the tagged shoots, washed several times with tap water, rinsed into distilled water and dried at $70^{\circ} \mathrm{C}$ to a constant weight. The dried leaves were ground and digested with sulphoric acid and hydrogen peroxide according to the method described by (Evenhuis and DeWaard, 1980). Suitable quantities were taken for mineral elements determination. Nitrogen and Phosphorus were determined colorimetrically according to (Evenhuis, 1976) and (Murphy and Riley,
1962), respectively. The contents of $\mathrm{Na}$ and $\mathrm{K}$ were determined by flame photometer E.E.L. Model (Jackson, 1967). The contents of $\mathrm{Ca}$ and $\mathrm{Mg}$ were determined by using versin (Chapman and Pratt, 1961). The content of $\mathrm{Cl}$ was estimated volumetrically as described by (Jackson, 1967), using silver nitrate and potassium dichromates reagents.

\section{6- Statistical analysis:}

Statistical analysis of the studied experiment was randomized complete block design and all data obtained throughout this present work were tested by analysis of variance (Little and Hills, 1998) and L.S.D test at 0.05 level was used for comparing between averages.

\section{RESULTS AND DISCUSSION. 1-Vegetative growth parameters:}

Data noticed from Table (4) showed plant height; stem diameter growth percentage and total shoot lengths of "Le-conte" pear young trees as affected by different rootstocks. There was significant variation among all rootstocks in both seasons. Pear plants budded on $P$. calleryana or beutilifolia gave the best effect on plant height; stem diameter growth percentage and total shoot lengths without significant differences between them compared to the lowest values recorded by the plants budded on $P$. communis. With respect to leaf area and specific leaf weight, data presented in Table (4) cleared that, there were significant differences obtained among rootstocks in both seasons. As for leaf area, plants grown on Pyrus calleryana stock gave the higher values than the other stocks in both seasons. However, the highest specific leaf weight recorded by Pyrus beutilifolia. The results of vegetative growth of this study generally indicated that pear trees were more vigorous on Pyrus calleryana or beutilifolia than on P.communis. These 
results are in line with those obtained by Matsumoto et al., (2006) and Abdel Aal (2009) found that the investigated growth traits were lower in "Le-Conte" grafted onto Pyrus communis, $P$. calleryana and $P$. beutilifolia in ascending order when irrigated by salinity water $(50 \mathrm{mM} \mathrm{NaCl})$, Salem et al. (2010) and Soliman (2010) mentioned that scions on Pyrus calleryana or beutilifolia had proved to be superior than on P.communis and appeared to be the most suitable rootstocks for "Le-Conte" pear cultivar during its early years of growth.

\section{2- Leaf water relations characteristics:}

Four physiological characteristics (total water content of leaf, free water content, bound water content and water deficit \%) were investigating regarding their response to effects of different rootstocks Table (5). With regard to total water content and free water content of leaf, data revealed that, plants grown on Pyrus beutilifolia followed by Pyrus calleryana gave the highest values in this respect compared to the lowest values resulted by plants grown on Pyrus communis in both seasons. On the contrary, bound water content and water deficit were increased in plants grown on Pyrus communis comparing with other rootstocks under study. The effect of the rootstocks on scion water relations were evaluated by Cohen and Naor (2002) on apple trees, Morsy (2003) on pear, Soliman (2010) on pear, Hemeed (2011) on grapevines. They showed that certain rootstocks are more efficient in water utilization than others may be due to better transpiration control and leaf anatomical structure.

Table (4): Effect of rootstocks on some growth measurements of pear transplants grown on saline alkaline heavy clay soil during 2014 and 2015 seasons.

\begin{tabular}{|l|c|c|c|c|c|l|l|l|l|l|}
\hline \multirow{2}{*}{ Rootstocks } & \multicolumn{2}{|c|}{$\begin{array}{c}\text { Plant height } \\
(\mathrm{cm})\end{array}$} & \multicolumn{2}{|c|}{$\begin{array}{c}\text { Stem diameter } \\
\text { growth }(\%)\end{array}$} & \multicolumn{2}{c|}{$\begin{array}{c}\text { Total shoot } \\
\text { lengths }(\mathrm{cm})\end{array}$} & \multicolumn{2}{|c|}{ Leaf area $\left(\mathrm{cm}^{2}\right)$} & \multicolumn{2}{|c|}{$\begin{array}{c}\text { Specific leaf } \\
\text { weight }\left(\mathrm{mg} / \mathrm{cm}^{2}\right)\end{array}$} \\
\cline { 2 - 12 } & 2014 & 2015 & 2014 & 2015 & 2014 & 2015 & 2014 & 2015 & 2014 & 2015 \\
\hline P. calleryana & 135 & 170 & 21.24 & 26.28 & 195.67 & 230.00 & 26.60 & 27.42 & 25.88 & 25.70 \\
\hline P. communis & 120 & 149 & 19.28 & 22.26 & 180.33 & 209.00 & 24.60 & 25.74 & 26.25 & 25.22 \\
\hline P. beutilifolia & 126 & 164 & 22.71 & 25.00 & 187.00 & 224.67 & 25.43 & 25.91 & 26.95 & 25.80 \\
\hline LSD at $5 \%$ & 6.22 & 9.45 & 2.162 & NS & 1.853 & 14.495 & 0.640 & 0.640 & 0.239 & 0.036 \\
\hline
\end{tabular}

Table (5): Effect of rootstocks on some leaf physiological properties of pear transplants grown on saline alkaline heavy clay soil during 2014 and 2015 seasons.

\begin{tabular}{|l|c|c|c|c|c|c|c|c|}
\hline \multirow{2}{*}{ Rootstocks } & \multicolumn{2}{|c|}{$\begin{array}{c}\text { Total water } \\
\text { content (\%) }\end{array}$} & \multicolumn{2}{c|}{$\begin{array}{c}\text { Free water } \\
\text { content (\%) }\end{array}$} & \multicolumn{2}{c|}{$\begin{array}{c}\text { Bound water } \\
\text { content (\%) }\end{array}$} & \multicolumn{2}{c|}{$\begin{array}{c}\text { Water deficit } \\
(\%)\end{array}$} \\
\cline { 2 - 9 } & 2014 & 2015 & 2014 & 2015 & 2014 & 2015 & 2014 & 2015 \\
\hline P. calleryana & 68.80 & 66.64 & 56.55 & 54.68 & 12.25 & 12.01 & 12.86 & 12.70 \\
\hline P. communis & 63.85 & 65.56 & 49.73 & 52.25 & 14.12 & 13.31 & 13.22 & 13.30 \\
\hline P. beutilifolia & 68.68 & 68.85 & 56.77 & 56.07 & 11.91 & 12.79 & 11.44 & 12.99 \\
\hline LSD at 5\% & 0.893 & 0.381 & 0.880 & 1.367 & 1.494 & 0.946 & 0.026 & 0.028 \\
\hline
\end{tabular}




\section{3- Leaf photosynthetic pigments and proline content:}

Table (6) showed that chlorophyll A, B and total chlorophyll were affected by the rootstocks. Hence, both chlorophyll A and B were significantly higher with Pyrus beutilifolia followed in decreasing order by $P$. calleryana and $P$. communis. As for total chlorophyll, there were non-significant differences among the rootstocks in both seasons. The decline in photosynthetic pigments content of salt-stressed plants budded on $P$. communis might be due to the decrease in the a absorption of minerals needed for chlorophyll biosynthesis specially under high soil $\mathrm{pH}$, i.e., iron and magnesium (Poljakoff and Gale, 1975) or due to inhibition of chlorophyll syntheses. Such findings are in harmony with those reported by Abd El-Kader et al., (2002), Darwesh (2006) Abdel Aal (2009), and Bosa et al., (2014) on pear trees.

With regard to the effect of different rootstocks on proline content of leaves under salinity conditions, leaves of pear plants grafted on $P$. communis rootstock had significantly higher value of proline comparing with those budded on the rest rootstocks that take the second rank without significant differences between them in the second season. The increasing of proline content in leaves of pear plants budded on $P$. communis rootstock showed the low tolerant to salt stress compared to $P$. calleryanan and $P$. beutilifolia. These results are confirmed by El-Sayed et al., (1996) on olive trees, Abdel Aal (2009) and Soliman (2010) on pear trees found that the more sensitive pear rootstock to salinity was $P$. communis, while the most tolerance pear rootstocks to salt stress were $P$. beutilifolia and $P$. calleryana. These differences to salinity tolerance among the studied pear rootstocks may be mainly due to the ability of each rootstock to exclude both $\mathrm{Na}$ and $\mathrm{Cl}$ ions in the roots.

\section{4- Leaf minerals content:}

As for the effect of rootstocks on leaf mineral composition of salt stressed pear transplants, data obtained in Tables (7 and 8) revealed obviously that, pear plants budded on P.calleryana rootstock had statistically the richest leaves in $\mathrm{N}$ content, while the reverse was true with those budded on $P$. communis in both seasons. While the richest leaves in $\mathrm{P}, \mathrm{Na}$ and $\mathrm{Cl}$ content recorded by plants grafted on $P$. communis but the other stocks take the second rank without significant differences between them. However. K percentage was increased in pear leaves, which budded on $P$. beutilifolia followed by P.calleryana rootstocks comparing with the lowest values obtained by plants budded on $P$. communis. As for leaves Ca content, data showed that plants budded on $P$. communis gave the highest value in the first season while in the second one plants budded on P.calleryana rootstock had statistically the richest leaves in $\mathrm{Ca}$ content compared to the lowest one resulted by $P$. beutilifolia in both seasons. Plants budded on P.calleryana or $P$. beutilifolia rootstocks gave the highest $\mathrm{Mg}$ content without significant differences between them. Such results are in general agreement with those obviously reported by Neilson and Kappel (1996) who reported that different rootstocks showed different ability to absorb ions, Matsumoto et al., (2006) showed that leaf $\mathrm{Na}$ and $\mathrm{Cl}$ contents for $P$. beutilifolia rootstock were lower than those for $P$. calleryana, $P$. pyrifolia, $P$. fauriei, and $P$. dimorphophylla rootstocks grown under saline conditions. The Japanese pear 'Akibae' grown on $P$. beutilifolia exhibits a higher salt tolerance than those grown on P. pyrifolia and $P$. calleryana. These results suggested that $P$. beutilifoliamay have a salt exclusion mechanism in the root, and this character was maintained even if scion cultivars were grafted. Therefore, $P$. beutilifolia is a useful rootstock for Japanese pear cultivation 
under saline conditions. In addition, Abdel Aal (2009) found that the more sensitive pear rootstock to salinity was $P$. communis, while the most tolerance pear rootstocks to salt stress were $P$. beutilifolia and $P$. calleryana. These differences to salinity tolerant among the studied pear rootstocks may be mainly due to the ability of each rootstock to exclude both $\mathrm{Na}$ and $\mathrm{Cl}$ ions in the roots.

Table (6): Effect of rootstocks on leaf photosynthetic pigments and proline contents of pear transplants grown on saline alkaline heavy clay soil during 2014 and 2015 seasons.

\begin{tabular}{|l|c|c|c|c|c|c|c|c|}
\hline \multirow{2}{*}{ Rootstocks } & \multicolumn{2}{|c|}{$\begin{array}{c}\text { Chlorophyll (A) } \\
\mathrm{Mg} / \mathrm{cm}^{2}\end{array}$} & \multicolumn{2}{c|}{$\begin{array}{c}\text { Chlorophyll (B) } \\
\mathrm{Mg} / \mathrm{cm}^{2}\end{array}$} & $\begin{array}{c}\text { Total Chlorophyll } \\
\mathrm{Mg} / \mathrm{cm}^{2}\end{array}$ & \multicolumn{2}{c|}{$\begin{array}{c}\text { Proline } \\
(\mathrm{mg} / \mathrm{gF} . W .)\end{array}$} \\
\cline { 2 - 9 } & 2014 & 2015 & 2014 & 2015 & 2014 & 2015 & 2014 & 2015 \\
\hline P. calleryana & 0.860 & 1.030 & 0.260 & 0.273 & 1.123 & 1.306 & 0.171 & 0.164 \\
\hline P. communis & 0.780 & 0.890 & 0.250 & 0.300 & 1.026 & 1.186 & 0.196 & 0.179 \\
\hline P. beutilifolia & 0.930 & 1.190 & 0.280 & 0.290 & 1.213 & 1.486 & 0.180 & 0.166 \\
\hline LSD at 5\% & 0.094 & 0.020 & 0.012 & 0.012 & 0.133 & NS & 0.002 & 0.003 \\
\hline
\end{tabular}

Table (7): Effect of rootstocks on leaf $\mathrm{N}, \mathrm{P}, \mathrm{K}$ and Ca content of pear transplants grown on saline alkaline heavy clay soil during 2014 and 2015 seasons.

\begin{tabular}{|l|c|c|c|c|c|c|c|c|}
\hline \multirow{2}{*}{ Rootstocks } & \multicolumn{2}{|c|}{$\mathrm{N}(\%)$} & \multicolumn{2}{c|}{$\mathrm{P}(\%)$} & \multicolumn{2}{c|}{$\mathrm{K}(\%)$} & \multicolumn{2}{c|}{$\mathrm{Ca}(\%)$} \\
\cline { 2 - 10 } & 2014 & 2015 & 2014 & 2015 & 2014 & 2015 & 2014 & 2015 \\
\hline P. calleryana & 2.29 & 2.92 & 0.14 & 0.14 & 1.48 & 1.34 & 2.65 & 2.71 \\
\hline P. communis & 1.97 & 2.37 & 0.16 & 0.18 & 1.29 & 1.18 & 2.87 & 2.58 \\
\hline P. beutilifolia & 2.12 & 2.21 & 0.13 & 0.15 & 1.57 & 1.50 & 2.52 & 2.52 \\
\hline LSD at 5\% & 0.028 & 0.395 & 0.020 & 0.026 & 0.027 & 0.041 & 0.012 & 0.028 \\
\hline
\end{tabular}

Table (8): Effect of rootstocks on leaf $\mathrm{Mg}, \mathrm{Na}$ and $\mathrm{Cl}$ content of pear transplants grown on saline alkaline heavy clay soil during 2015 and 2016 seasons.

\begin{tabular}{|l|c|c|c|c|c|c|}
\hline \multirow{2}{*}{ Rootstocks } & \multicolumn{2}{|c|}{$\mathrm{Mg}(\%)$} & \multicolumn{2}{c|}{$\mathrm{Na}(\%)$} & \multicolumn{2}{c|}{$\mathrm{Cl}(\%)$} \\
\cline { 2 - 7 } & 2014 & 2015 & 2014 & 2015 & 2014 & 2015 \\
\hline P. calleryana & 0.34 & 0.33 & 0.90 & 0.96 & 1.22 & 1.34 \\
\hline P. communis & 0.31 & 0.28 & 1.10 & 1.10 & 1.88 & 1.78 \\
\hline P. beutilifolia & 0.35 & 0.36 & 0.92 & 0.90 & 1.24 & 1.29 \\
\hline \multicolumn{1}{|c|}{ LSD at 5\% } & NS & 0.042 & 0.103 & 0.060 & 0.038 & 0.116 \\
\hline
\end{tabular}




\section{CONCLUSION}

The present results clearly showed that Pyurs beutilifolia and $P$. calleryana induced better vegetative growth (plant height, stem diameter, shoot length and leaf area), leaf water relations (total leaf water content and free water content), photosynthetic pigments (chlorophyll A, B and total) as well as leaf minerals content $(\mathrm{N}, \mathrm{K}$ and $\mathrm{Mg})$. On the other hand, "Le-Conte" pear budded on $\mathrm{p}$. communis has higher bound water, water deficit, proline, $\mathrm{P}, \mathrm{Na}$ and $\mathrm{Cl}$. So, we recommend "Le-Conte" pear growers to budded their transplants on pyrus calleryana or $p$. beutilifolia to have benefits of better vegetative growth, leaf water relations, photosynthetic pigments and leaf mineral content specially on heavy clay soil.

\section{REFERENCES}

Abdel Aal, A. M. K. (2009). Alleviating the adverse effects of water salinity on growth and water consumption of LeConte' pear transplants by using sitofix (CPPU) and some pear rootstocls. Minufiya J. Agric. Res. 34 (1): 127-145.

Abdel-Hafez, S.A. (2011). Opportunities and challenges in the old lands of Egypt. Background paper for the Egypt-Australia-ICARDA workshop on-farm water-use efficiency, 26-29 July 2011, Egypt.

Abdel-Kader, H.M., S.M. Sabbah and A.A. El-Sayed (2002). Effect of salt stress on leaf proline accumulation and chlorophyll content of some fruit species. J. Adv. Agric. Res, 7 (4): 873-884.

Barrs, H. D. (1968). Determination of water deficit in plant tissues .In water deficit and plant growth (Kozlowski, T.T.,ed) 1:236-238.Acamemic press ,New York

Batels, L. S., R. P. Waldren and I. D. Teare (1973). Rapid determination of free proline for water stress studies. Plant and Soil; 939: 205-207.

Bosa, K., E. Jadczuk, M. H. Kalaji, M. Majewska and S. I. Allakhverdiev (2014). Evaluating the effect of rootstocks and potassium level on photosynthetic productivity and yield of pear trees.
Russian Journal of Plant Physiology, 61 (2), 231-237.

Chapman, H.D. and P. F. Pratt (1961). Methods of Analysis for Soils, Plants, and Water. Univ. of California Division of Agric. S.I. (2001). Comparative Evaluation of known Liquid Humic Analysis Method. Arctech Inc, Chantill, VA20165, USA.

Cohen, S. and A. Naor (2002). The effect of three rootstocks on water use, canopy conductance and hydraulic parameters of apple trees and predicting canopy from hydraulic conductance. Plant Cell and Environment, 25: 17-28.

Darwesh, D.R. (2006). Physiological and anatomical studies on tolerance of some fruit rootstocks to salinity. M.Sc. Thesis Fac. Of Agric., Benha Univ., Egypt.

Draz, M. Y. (1986). Response of bitter almond seedling to different water regime. Ph. D. Thesis Fac. of Agric., Cairo Univ. Egypt.

El-Sayed, E.H., M.E. Said, A. H. El-Sherif and S.A. Sari-El-Deen (1996). Chemical studies on the salt tolerance of some olive cultivars. Olivae, 64: 52-57.

Evenhuis, B and P.W.Dewaard (1980). Principles and practices in plant analysis .F.A.O. Soil bull. 39(1):152-162.

Evenhuis, B. (1976). Nitrogen determination.Dept. Agric.Res. Royal. Tropical Inst. Amsterdam.

Ferree, D.C. and C.G. Forshey (1988). Influence of pruning and urea sprays on growth and fruiting of spur-bound 'Delicious' apple trees, J. Amer. Soc. Hort. Sci. 113:699-703.

Francois, L.E and E.V. Maas (1994). Crop response and management on saltafffected soils, p. 149-181. In: Pessarakli, M., (Eds.). Handbook of Plant and Crop Stress, Marcel Dekker, New York.

Gosev, N. A. (1960). Some methods in studying plant water relations press of Soviet Society for Potential Science, U. S. S. R (pp.60).

Hemeed, A. A. R. (2011). Growth evaluation of some grape cultivars and rootstocks under saline stress conditions Ph. D. Thesis Fac. of Agric., Cairo Univ. Egypt. 
Jackson, M. L. (1973). Soil Chemical Analysis prentice Hall of India Private, LTD, New. Delhi.

Jackson, N. L. (1967). Soil Chemical Analysis. Prentice. Hall Inc. Englewood Cliffs, New Jersy.

Klute, A. (1986). Water Retention; Laboratory Methods .In: A. Koute (ed.) methods of soil Analysis ,Part 1-2 ${ }^{\text {nd }}$ ed. Agron ,W,U.S.A.,PP:635-660

Koshnirinko, M. D., A. A. A. Gonsharova and E.M. Bondar (1970). Method of studying water relations and drought resistance of fruit trees .Acad. Sci. Press. Maldovia,U.S.S.R(pp53-61)

Lauchli and A.E. Epstein (1990). Plant Responses to Saline and Sodic Conditions," In: K. K. Tanji, Ed., Agricultural Sa- linity Assessment and Management. Manuals and Re- ports on Engineering Practice, ASCE, New York, pp. 113-137.

Little, T.M. and F.J. Hills (1998). Agriculture experimentation, design and analysis. Jhon Willey and sons, New York.

Ma, C.H., K. Tanabe, A. Itai, F. Tamura, J. P. Chun and Y. W. Teng (2005). Tolerance to lime-induced chlorosis of Asian pear rootstock (pyrus sp.). J. Jap. Sci. 34 (6):419-423.

Mass, E.V and G.J. Hoffman (1977). Crop salt tolerance. J. Irrig. Drain. Div. 103:115-134.

Matsumoto, K., J. P. Chun, F. Tamura, Y. Kamamoto and K. Tanabe (2006). Salt tolerance in Pyrus species is linked to levels of $\mathrm{Na}$ and $\mathrm{Cl}$ translocation from roots to leaves. Journal of the Japanese Society for Horticultural Science. 75:385391.

Moran, R. (1982). Formulae for determination of chlorophyllous pigments extracted with $\mathrm{N}, \mathrm{N}$-Dimethel Formamide .plant physoil.69, 1376-1381.

Morsy, M.H. (2003). Water consumption and growth of apple and pear transplants as influenced by rootstocks and GA3 application. Minia J. Agric. Res. \&Develop. 23(4):629-648.
Munns, R (1993). Physiological processes limiting plant growth in saline soil: some dogmas and hypotheses," Plant, Cell \& Environment, 16: 15-24.

Murphy, J. and J. P. Riley (1962). A modified single solution method for the determination of Phosphorus in natural water. Anal. Chemi. Acta. 27:13-36.

Neilsen, G. and F. Kapple (1996). Bing sweet cherry leaf nutrition is affected by rootstock. Hort. Science, 31:1169-1172.

Okubo, M., Y. Furukawa and T. Sakuratani (2000). Growth, flowering and leaf properties of pear cultivars grafted on two Asian pear rootstock seedlings under $\mathrm{NaCl}$ irrigation. Scientia Horticulturae. 85:91-101.

Poljakoff and T. Gale (1975). Physiological basis for the reduction of plant growth under conditions of irrigation with brackish water and possible methods of amelioration. International Symposium of Brackish Water as a Factor in Development. Pp.97-102.

Robbani, M., K. Banno, K. Yamaguchi, N. Fujisawa, J.Y. Liu and M. Kakegawa (2006). Selection of dwarfing pear rootstock clones from pyrus beutilifolia and $P$. calleryana seedlings.J.Jap.Sci. 75 (1):1-10.

Salem, A.T., T. A. Fayed, L. F. Hagagg, $H$. A. Mahdy and S. A. Elshall (2010). Effect of rootstocks, organic matter and different nitrogen levels on growth and yield of Le-Cont pear trees. J. Hort. Sci. \& Ornamen. Plants, 2 (3): 130-147.

Shrivastava, P. and R. Kumar (2015). Soil salinity: A serious environmental issue and plant growth promoting bacteria as one of the tools for its alleviation. Saudi J Biol Sci; 22(2): 123-131.

Soliman, M.A. (2010). Physiological and histological studies on salt tolerance of pear grown on different rootstocks. Ph. D. Thesis Fac. of Agric., Kafrelsheikh Univ. Egypt.

Wheaton, T. A., W. S.Castel, J.D. Whitney and D. P. H. Tucker (1991). Performance of citrus scion cultivars and rootstocks in a high-density planting. Hortscience, 26: 837-840. 


\title{
تقييم شتلات الكمثرى المطعومة على أصول مختلفة في منطقة شمال وسط دلتا النيل
}

\author{
محمد على محمد سليمان ، محمد محمد سعد أبو العنين
}

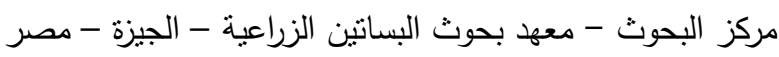

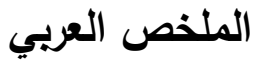

أجريت هذه الدراسة خلال موسمي 2014 2015 2015 بمزرعة محطة بحوث البساتين بسخا محافظة كفر الثنيخ

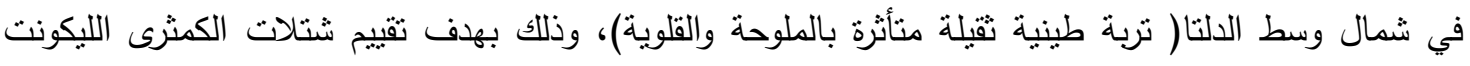

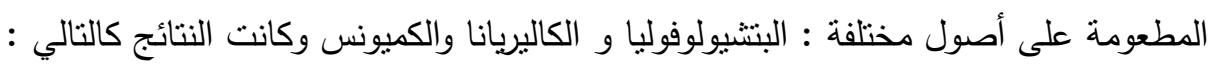

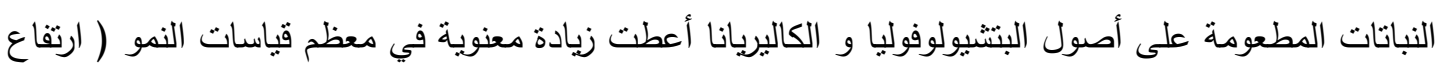

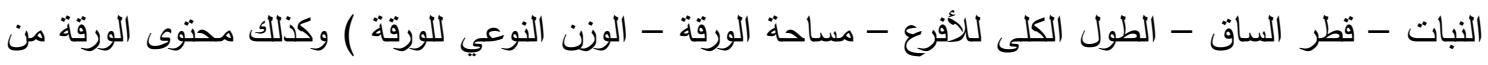

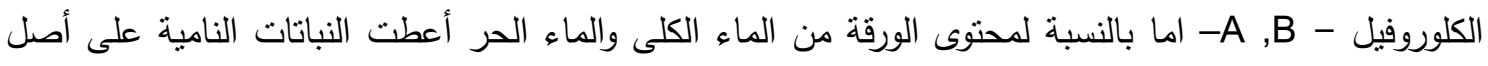

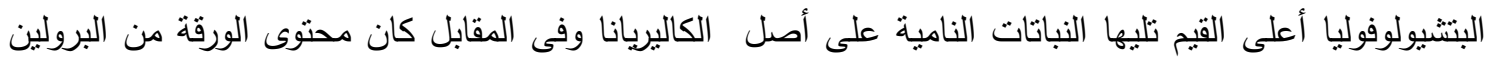

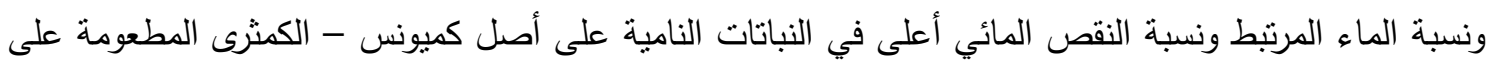

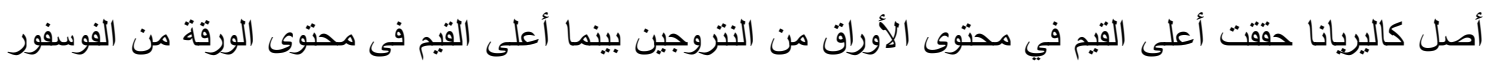

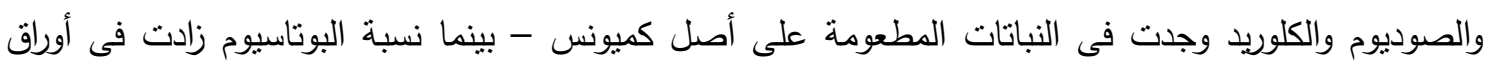

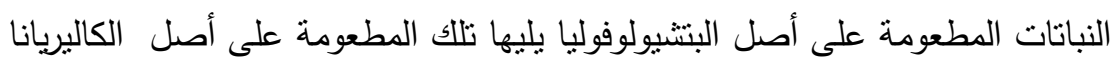

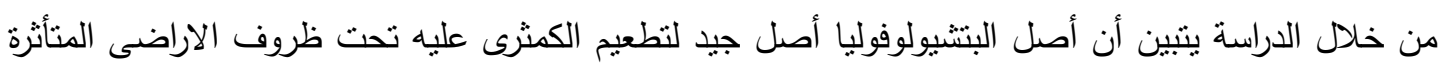
بالملوحة والقلوية.

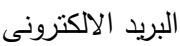

E-mail:mujareg@gmail.com
موقع المجلة

Mujareg.blogspot.com 
